LODJ

29,1

4

Received January 2007

Revised April 2007

Accepted May 2007

\section{Growing transformational leaders: exploring the role of personality hardiness}

\author{
Jarle Eid and Bjørn Helge Johnsen
}

Department of Psychosocial Science, The University of Bergen, Bergen, Norway

Paul T. Bartone

The National Defense University, Washington, DC, USA, and

Odd Arne Nissestad

The Royal Norwegian Navy, Bergen, Norway

\begin{abstract}
Purpose - The purpose of this paper is to evaluate the role of personality hardiness in facilitating change or growth in transformational leadership of Norwegian Navy cadets following a stressful military training exercise.

Design/methodology/approach - Leadership styles were measured in cadets before and after an intensive leadership training exercise, and again six months later. Hardiness was measured near the end of the first academic year. Leader performance was measured with first year leader development grades.

Findings - Repeated measures ANOVAS showed a sustained increase in transformational and transactional leadership following the exercise, and a decrease in the passive-avoidant style (management by exception - passive and laissez-faire). Hardiness was associated with more Transformational and less Passive-avoidant leadership at all measurement points. Also, hardiness predicted short- and long-term increases in Transformational leadership following the exercise. Transformational and Transactional styles also predict leader performance grades.

Research limitations/implications - This research was conducted with a relatively small group and findings may not generalize readily to other populations.

Practical implications - These results suggest high hardy individuals have a greater readiness to make use of stressful training experiences as opportunities for developmental growth as leaders.

Originality/value - This study is the first of its kind to explore the role of a key personality variable - hardiness - to facilitate positive benefit from a real-world training experience designed to develop better leadership capabilities. Further, it is one of few studies to identify factors contributing to the growth transformational leadership style. A strength of the study is that it was conducted in the context of a real-world leadership training activity.
\end{abstract}

Keywords Transformational leadership, Leadership development, Armed forces, Personality, Process analysis, Norway

Paper type Research paper

Beginning with Burns' (1978) formulation, theories of charismatic and transformational leadership have sparked a renewed interest in individual differences as predictors of effective leadership (Bass, 1985; Burns, 1978; House and Shamir, 1993). Consistent with Burns' initial views, Bass (1985) conceptualized transformational leaders as unique motivators who encourage followers to go beyond their believed capabilities in pursuit of a shared, common goal. The significance of transformational leadership has been elaborated in the so-called Full Range of Leadership Model (Avolio and Bass, 1991). This

widely researched model describes three main types of leadership behaviour:
Leadership \& Organization

Development Journal

pp. $4-23$

(C) Emerald Group Publishing Limited 0143-7739

DOI 10.1108/01437730810845270 
(1) transformational;

(2) transactional; and

(3) laissez-faire.

In the Full Range of Leadership Model (FRLM), Bass (1998) divided transformational leadership into four components. Idealized Influence involves inspiring visions, sharing risks and hardships, and earning trust and confidence from subordinates. Leaders who exert idealized influence behave in ways that demonstrate high standards of ethical and moral conduct (Bass, 1998). Inspirational motivation involves showing enthusiasm and optimism in ways that motivate those around one by providing meaning and challenges. Followers of such leaders often report being enthusiastic, optimistic and cooperative (Avolio, 1999). Intellectual stimulation entails stimulating efforts to find new ideas and creative solutions to problems, encouraging innovation, creativity, and new approaches. Such leaders solicit new ideas and innovative solutions from followers, and they encourage followers to present ideas that are different from their own. Finally, individualized consideration is about recognizing that subordinates have different needs and desires, and acting as a coach in order to develop their full potential. Leaders who express individualized consideration facilitate the growth of their followers by assigning tasks that are appropriate to each person's competencies and skills.

Bass further divided transactional leadership into three components. When using contingent reward, leaders provide positive reinforcement that is contingent upon performance. In the management-by-exception - active style, the leader monitors followers and intervenes when problematic behaviour is identified. Then the leader specifies the behavioral standards for compliance as well as those behaviors that constitute ineffective performance. In the management-by-exception - passive style, the leader responds to errors and corrects problems only if they surface in some unavoidable way. Another aspect of this style is the tendency for leaders to apply punishment in non-contingent ways (Atwater et al., 1998).

In addition to the transformational and transactional styles, Bass also described a laissez-faire style as a distinct form of dysfunctional leadership behavior. Laissez-faire leadership is characterized by absence or the avoidance of leadership responsibility. Later research has suggested that the two negative transactional dimensions of management by exception - passive and Laissez-faire should be combined to provide a better overall model. In the revised version, this consolidated negative dimension is called Passive - avoidant leadership (Avolio et al., 1999; Bass and Avolio, 1994; Den Hartog et al., 1997). Based on a principal component analysis of data from Norwegian business managers, Hetland and Sandal (2003) found that the dimensions of contingent reward and management-by-exception - active could be combined into a coherent (positive) Transactional leadership dimension. In his FRLM, Bass states that leaders must master all components in order to be effective, but should employ the transformational components most frequently, which in turn substantially augments the effects of transactional leadership (Bass, 1998).

Multiple empirical studies have provided general support for the hypothesized relations between transformational and transactional leadership and performance (Avolio, 1999; Bass, 1998; Bass et al., 2003). Research has also supported the so-called augmentation hypothesis, indicating that in most situations transformational 
LODJ 29,1

leadership behavior will augment that of transactional leadership (Kane and Tremble, 2000; Waldman et al., 1990). Transformational leadership has been positively correlated with supervisor evaluations of managerial performance (Hater and Bass, 1988; Waldman et al., 1987), recommendations for promotion (Waldman et al., 1990), project team innovations (Keller, 1999), financial outcome indicators (Howell and Avolio, 1993), and increased situational awareness (Eid et al., 2004). Meta-analyses have also confirmed a positive relationship between transformational leadership and performance as reported in the literature (Lowe et al., 1996; Patterson et al., 1995).

\section{Personality hardiness and leader development}

Several recent reviews of the leadership training literature have observed there is a paucity of empirical studies on how to identify and develop high performing leaders (e.g. Day, 2001; Yukl, 1999). It is also well known that individuals do not respond in the same way to similar training conditions. An important task in this area is thus to identify potential factors that may influence how quickly or effectively various experiences result in growth or development as a leader. To explore this question, the present study will examine the role of personality hardiness as a potential facilitating factor in the making of transformational leaders.

Conceptually, hardiness is a personality dimension that develops early in life and is reasonably stable over time (Kobasa, 1979; Maddi and Kobasa, 1984). Hardy persons have a high sense of life and work commitment, a greater belief of control, and are more open to change and challenges in life. They tend to interpret stressful and painful experiences as a normal aspect of existence, part of life that is overall interesting and worthwhile. In a variety of occupational groups, hardiness has been associated with good health and performance under a range of stressful conditions (Bartone, 2000; Bartone et al., 1989; Kobasa, 1979). Other studies point to hardiness as a significant moderator or buffer of stress (e.g. Contrada, 1989; Kobasa et al., 1982; Roth et al., 1989; Wiebe, 1991). In military groups, hardiness has also been identified as a significant moderator of combat exposure stress in Wartime conditions (Bartone, 1999; Bartone et al., 1989) and during combat training (Florian et al., 1995; Westman, 1990).

A critical aspect of the hardiness resiliency mechanism likely involves the interpretation or the meaning that people attach to events around them and their own place in this world of experiences (Bartone, 2006; Ouellette, 1993). High hardy individuals believe they can control or influence events, and are strongly committed to activities and their interpersonal relationships and to self, in that they recognize their own distinctive values, goals and priorities in life. People high in hardiness also tend to interpret stressful events in positive and constructive ways, and construe such events as a challenge and a valuable learning opportunity (Bartone, 2000). Thus, hardiness seems to be a particularly relevant personality dimension that could be related to leader development in challenging and intensive leader development programs. There are also empirical grounds for examining hardiness in relation to transformational leadership. In a study of US Army cadets, Bartone (1999) found that hardiness and transformational leadership were significant unique predictors of West Point leadership grades. At the same time, hardiness (commitment facet) was moderately correlated with transformational leadership, which could reflect an influence of hardiness on transformational leadership style. 
Theoretically, the construct of personality hardiness should relate in particular to transformational leadership because those high in hardiness tend to interpret new experiences as:

- overall interesting and worthwhile;

- challenging opportunities from which to learn and grow; and

- external events they can influence and exert control over.

While the control dimension may also be important for transactional leadership (e.g. to facilitate exchange tactics and administer timely rewards), the personality hardiness facets of commitment and challenge should be more closely related to transformational leadership, perhaps providing a developmental readiness to grow and develop as leaders. A highly committed person would be more interested and involved in the surrounding physical world, the social world of other people, and the world of his/her own inner-self. An individual who is high in the hardiness facet of challenge would thus be more inclined to accept and adapt to a demanding and stressful learning environment. In such settings, transformational leaders are expected to enhance the performance capacity of their followers by setting higher expectations and generating a greater willingness to address more difficult challenges (Avolio, 1999; Bass, 1998). We would therefore predict that personality hardiness contributes to a person's developmental readiness or potential to grow and adapt as leader.

\section{Leader development}

Although the literature on transformational and transactional leadership has grown rapidly over the past 15 years, only a handful of studies have examined how transformational and transactional leadership behaviours are developed. According to Popper and Mayseless (2003) psychological mechanisms related to parenting processes can serve as an analogue model for the relations between transformational leaders and followers. Other studies have suggested that early family factors and parental style could play an important role in promoting transformational leadership behaviour (Avolio and Gibbons, 1998; Zacharatos et al., 2000). Still other studies have indicated that more specific developmental programs can affect leadership style. For example, a field experiment conducted within a Canadian banking institution found transformational leadership training enhanced follower commitment and organizational performance (Barling et al., 1996). Another field experiment with Israeli platoon leaders also showed that transformational leadership could be developed, and that it had a positive impact on unit performance six months after the training (Dvir et al., 2002). Leaders who received transformational leadership training led platoons that showed higher levels of effort and performance.

Some systematic leader development programs have adopted an "action learning" process, which can be described as a continuous process of supervised learning and reflection (Pedler, 1997). Increased self-awareness and a better capability to express and monitor one's own behaviors are frequently cited as goals of leader development programs. This is most often accomplished within an action learning approach, where leadership development is enhanced to the extent that structured opportunities for individual and group reflection are included in the form of 360-degree or multi-source feedback (Alimo-Metcalfe, 1998). Such systematic and structured interpretation of critical learning experiences also appears to be a significant aspect of personality
The role of personality hardiness 
LODJ

29,1

hardiness; theoretically, high-hardy individuals should routinely attend more carefully to events around them, while also monitoring their own actions over time.

Equally important for leadership development, is the task or job assignment associated with specific organizational roles and facing of new external demands. Developmental tasks or job assignments are typically associated with new and challenging responsibilities, which require an individual to bring about change or build new personal relationships and commitment. In systematic leader development efforts, such experiences tend to be associated with significant learning and development, and this extends also to negative experiences and hardships (Day, 2001). These aspects of leadership development can be recognized as core elements in many of the leadership training programs and training exercises at the US and European military service academies (Bartone, 2001).

\section{Leadership development at the Royal Norwegian Naval Academy}

Every year about 80 officer candidates are admitted to the three-year study program at the Royal Norwegian Naval Academy. After completing the Naval Academy, the officer cadets are qualified for a lifelong career in the Navy or Coast Guard. At the end of their first year at the Naval Academy, the Norwegian Navy officer cadets undergo a stressful weeklong exercise in squad-size groups of seven to nine individuals. The leadership development program and field training exercise are designed in accordance with the general principles of maneuver warfare (Wats, 1996), which has an explicit emphasis on distributed decision making, flexibility, autonomy and initiative. Although the exercise is not intended to teach the cadets about the full range of leadership theory, many of the exercise elements could be interpreted within this framework. In order to accomplish a series of relatively demanding missions over a one-week period, the squad leaders will have to share risks and hardships in order to earn trust and confidence from their followers (idealized influence), they must be able to care for other team members (individualized consideration), effectively formulate and communicate goals and visions of the near future (inspirational motivation), and encourage innovation and creative problem solving of followers (intellectual stimulation). Thus, the leader development exercise provides a unique personal experience where the cadets are engaged in a series of challenging true to life simulations involving teamwork and problem solving.

Previous studies of similar leadership development exercises at the Norwegian Naval Academy have demonstrated that intensive team training experiences produce an effect on leader preferences, status hierarchies and group polarization in the cadets (Polley and Eid, 1990, 1994). In a recent study, Bartone et al. (2002) found that intensive and demanding military training experiences contributed to increased group cohesion in familiar as well as unfamiliar military teams. With respect to military groups, good leadership is commonly seen as an important influence on morale and group cohesion. Several authors have suggested that leaders who are perceived by soldiers as caring and competent can influence the development of cohesion in a positive way (Griffith, 1988; Ingraham and Manning, 1981; Kirkland et al., 1993).

Although previous studies have indicated that small unit leadership could be linked to important outcome variables at the individual and team level, few studies have sought to empirically determine if individual differences in personality are related to leader development. The present study contributes to this literature by examining the role of 
personality hardiness in developing leadership behaviour in a naturalistic setting. One advantage of the military training environment is that Navy Officer cadets represent a relatively homogeneous group in which all are exposed to relatively well-controlled interventions and challenging true-to-life exercises. Furthermore, this study employs a longitudinal design in which a group of cadets are followed over time. Since the Norwegian Naval Academy also utilizes quite precise systems of performance appraisal and behaviorally anchored assessments of leader effectiveness, these indicators can provide an independent index of leader effectiveness. Specifically, we will address the following three research aims and hypotheses.

Assess any changes in self-ratings of leadership style over time. Based on the careful design and overall purpose of the leader development program, we expect to see significant changes in cadet self- ratings of leadership behavior over time:

H1. Transformational and transactional leadership style will show a sustained increase, while passive-avoidant leadership style will decrease following the exercise.

Evaluate whether personality hardiness is associated with changes in leadership style after the exercise. Taking into consideration the highly stressful and challenging nature of the training exercise, we expect that individual differences in how stressful and frustrating personal experiences are approached, as indicated by hardiness, will serve as a positive precursor for change, a "developmental readiness" factor.

H2. Personality hardiness will be associated with increases in transformational and (positive) transactional leadership styles, and with decreases in passive-avoidant styles following the exercise.

As a check on the behavioral significance self-rated leadership styles and personality hardiness, these indicators can be compared against an independent, objective performance measure - the Military Development Grade (MDG). We postulated that leadership styles and personality hardiness would predict Military Development Grades assigned to the Navy Officer cadets at the end of their first year at the Academy.

H3. Transformational and transactional leadership styles and personality hardiness will positively predict MDG, while passive-avoidant style will negatively predict MDG.

\section{Method \\ Participants}

The participants in the present study were members of the year 2000 cohort from the Royal Norwegian Naval Academy $(N=72)$. A total of 67 cadets (93 per cent) agreed to participate at one or more of the time points, and 66 cadets (92 per cent) completed questionnaires at all three measurement points. Mean age for the cadets who responded at all measurement points was 24.42 years $(S D=4.47$; range 20-36 years). In this sample, 65 cadets were male and one was female. All participants had a minimum of one year of military service before entering the RNoNA, and they were screened for basic health and mental aptitude prior to admission.

\section{The role of personality hardiness}




\section{LODJ 29,1}

\section{Procedure}

As part of their three-year officer development program, all cadets at the Royal Norwegian Naval Academy (RNoNA) participate in a weeklong training exercise and field simulation near the end of their first year. The main objective of the exercise is to provide cadets with an opportunity to develop and demonstrate team leadership in critical and demanding situations. The exercise presents a simulated sustained field operation, with cadets performing various military tasks including naval operations and field training. During the course of the exercise cadets receive a minimum of food and obtain little sleep. The cadets operate in squad -size units of about seven to nine persons. The leader role is rotated within the group, until all cadets have been exposed to at least one period of about 16-18 hours as a squad leader. After each period, leader behavior and performance is assessed and evaluated by all the team members, and a new cadet is assigned to take over the team leader role. These performance appraisals and feedback sessions are carried out in the field setting, and are facilitated by a coach from the Naval Academy staff. In this way each cadet observes and reflects on the leader behavior of fellow cadets, in addition to receiving feedback on his own performance as team leader (developmental assessments were not available for research purposes).

One significant element of the exercise is a 24-hour prisoner of war (POW) simulation. This is a highly realistic simulation in which the cadets experience the shock of capture and blindfolded movement, lack of food and sleep, confinement in a prison yard, and intense questioning by trained interrogators. Previous research has confirmed this is a highly stressful experience for Norwegian officer cadets (Eid et al., 1998). This training element is followed by a detailed debriefing and feedback session (Laberg et al., 2000).

Self-ratings of leadership style were collected just prior to the beginning, and again one week following completion of the leadership exercise. Follow-up data on leadership style and personality hardiness were collected six months after the leadership exercise. On each occasion questionnaire instruments were administered in a classroom setting at the Academy. While the exercise itself was a mandatory part of the leadership training, participation in the present study was voluntary. Responses were coded anonymously, and individual scores were not available to the Academy staff.

\section{Measures}

The Multifactor Leadership Questionnaire (MLQ-5X; Avolio and Bass, 2002) was used to obtain self-ratings of leadership behavior. The MLQ questionnaire contains 45 items describing behavior and attributions, each rated on a five-point scale $(0=$ rarely, $4=$ to a large extent). Permission was obtained from the MLQ developers to use their scale for the purpose of this research. We used a Norwegian translation, produced through a back-translation procedure. In the present study we extracted three outcome variables indexing transformational ( $\alpha=0.86$ to 0.87 ), transactional ( $\alpha=0.55$ to 0.61 ), and passive-avoidant ( $\alpha=0.68$ to 0.80$)$ leadership behavior. In addition, facet scores for the three dimensions were constructed. The transformational facets of idealized influence, inspirational motivation, intellectual stimulation, and individualized consideration were intercorrelated in the range of $r=0.31$ to 0.71 . The transactional facets of contingent reward and management by exception-active were intercorrelated 
in the range of $r=0.18$ to 0.32 . Finally, the passive-avoidant facets of management by exception - passive and laissez-faire revealed intercorrelations ranging from $r=0.31$ to 0.51 .

Hardiness was measured at the six-month follow-up with a Norwegian translation of the short form of the Dispositional Resiliency Scale reported by Bartone (1995). This 15 -item scale (rated on a four-point scale from $0=$ not at all true, to $3=$ completely true) measures the hardiness facets of commitment, control and challenge, and has shown good reliability and validity across a wide range of samples (Bartone, 2000). For this scale, three-month test-retest reliability is reported at 0.78 (Bartone, 1998), indicating a high level of stability of hardiness scores over time. For the hardiness scale, a split-half reliability coefficient gives a more accurate estimate of reliability than Cronbach's alpha coefficient. This is because hardiness is a heterogenous construct, and content heterogeneity is a source of error for the alpha coefficient, but not for split-half techniques (Anastasi, 1988, pp. 122-6). In the present sample, the Guttman split-half reliability coefficient for the overall hardiness scale was 0.74 . As could be expected, the hardiness scale has proved to be very stable over time with a ten-month test-retest reliability of $0.62(p<0.001)$ in a sample $(N=70)$ of Norwegian Navy cadets[1].

Military development (MD) grades are one of the most important and comprehensive indicators of leadership effectiveness in Norwegian officer cadets. This is a performance score or grade assigned to cadets at the end of each year at the Naval Academy, and is a weighted average of performance ratings by three to four key supervisors from the military and academic staff. MD ratings focus on personal attributes such as interpersonal influence, initiative, trust, and individualized consideration. MD ratings reflect military performance and leadership, and take the form of a decimal point grade (range: $1.0=$ Excellent to $4.0=$ Poor). For the present study, MD grades from the first year at the Naval Academy were used as the primary outcome measure. The key supervisors who assigned the MD grades were blind to the Naval Officer cadets' self-ratings of leadership style and the MD grades were assigned after the cadets had completed their academic exams, about three weeks after the leader development exercise had ended.

\section{Statistics}

Cronbach's alpha and Guttman's split-half statistics were computed as reliability measures. Pearson product-moment correlations were computed as an initial assessment of change or stability in levels of individual self-ratings of leadership style over time. This was followed by repeated-measures ANOVAS to more precisely evaluate the significance of any changes in transformational, transactional, and passive-avoidant leadership styles. Next, a series of stepwise regressions were performed to test for effects of personality hardiness and the three hardiness facets on leadership styles following the exercise. In these regressions, the relevant time 1 leadership scores were entered first to control for pre-exercise levels. Once the time 1 leadership effects are removed in this way, it is any change in leadership style that remains to be predicted. Finally, stepwise regression was used to test for effects of leadership style at each time point on Military Development grades assigned at the end of the first year.

\section{The role of personality hardiness}




\section{LODJ 29,1}

\section{2}

\section{Results}

Leadership style

Pearson product-moment correlations showed relatively high correlations over time for ratings of transformational style (0.65 to 0.71 ) and passive-avoidant style (0.63 to 0.74 ), while the correlations for transactional style were moderately high (0.45 to 0.54$)$, indicating strong relative stability in individual self-ratings of leadership style over the three measurement points ( $N=67, p<0.001$ in all cases).

Results for the repeated measures ANOVAs examining leadership styles over time are summarized in Table I, which also displays the means and standard deviations for the various leadership styles over time. Findings show significant increases after the exercise in both transformational and transactional leadership styles, and decreases in passive-avoidant style. These differences are all maintained six months after the exercise, and transformational leadership style has increased even more. There are no significant differences from time 2 (after the exercise) to time 3 (six-month follow-up).

\section{Personality hardiness and leadership style}

The mean level for personality hardiness in this sample was 30.95 (s.d. = 4.49). Positive correlations were found between commitment and the facets of control $(r=0.50, p<0.01)$ and challenge $(r=0.42, p<0.01)$, while no correlation were found between challenge and control ( $r=0.06$, n.s.). Several stepwise regressions tested for the possible influence of hardiness and the three hardiness facets on change in leadership style following the exercise, controlling for pre-exercise leadership style levels. Table II displays these results for transformational leadership, Table III for transactional leadership, and Table IV for passive-avoidant leadership style. In each case, two models were run in order to clarify the relative influence of total hardiness and the three facets. The first model adds just total hardiness scores to the predictor set (with the control variable, time 1 leadership style). The second model adds just the three hardiness facets. These two regression models were evaluated first for leadership level immediately after the exercise as the dependent variable, and then again for leadership level at the six-month follow-up point. Again in all regression models, the relevant time 1 (baseline) leadership style score was first removed in order to identify any effects of hardiness on change in leadership style.

Looking first at the results for transformational leadership (Table II), in all models the time 1 (baseline) levels of transformational leadership exert the biggest influence on levels

\section{Table I.}

Repeated measures ANOVAs on leadership styles over time in Navy officer cadets, means and (sds)

\begin{tabular}{lccc}
\hline Leadership style & $\begin{array}{c}\text { a. Before exercise } \\
\text { (time 1) }\end{array}$ & $\begin{array}{c}\text { b After exercise } \\
\text { (time 2) }\end{array}$ & $\begin{array}{c}\text { c. Six-month follow-up } \\
\text { (time 3) }\end{array}$ \\
\hline Transformational & $2.54^{\mathrm{bc}}$ & $2.72^{\mathrm{a}}$ & $2.78^{\mathrm{a}}$ \\
& $(0.38)$ & $(0.37)$ & $(0.37)$ \\
Transactional & $2.27^{\mathrm{bc}}$ & $2.56^{\mathrm{a}}$ & $2.55^{\mathrm{a}}$ \\
Passive-avoidant & $(0.39)$ & $(0.37)$ & $(0.38)$ \\
& $1.39 \mathrm{bc}$ & $1.31^{\mathrm{a}}$ & $1.29^{\mathrm{a}}$ \\
& $(0.51)$ & $(0.48)$ & $(0.40)$
\end{tabular}

Notes: $n=67 ; p<0.05$ for all contrasts except passive-avoidant time 1 vs time 2 , where $p<0.06$; ${ }^{a}$ Indicates a significant difference from the (a) time point; ${ }^{b}$ Indicates a significant difference from the (b) time point; ${ }^{\mathrm{c}}$ Indicates a significant difference from the (c) time point 
after the exercise, accounting for 44 percent to 45 percent of the variance in later levels. Next, total hardiness is seen to have a significant effect on increases in transformational leadership right after the exercise (model 1a, $R^{2} \Delta=0.07, p<0.01$ ), an effect that is even stronger at the six-month follow-up point (model $1 \mathrm{~b}, R^{2} \Delta=0.12, p<0.01$ ). When just the hardiness facets are entered, control emerges as a significant predictor just after the exercise, but at the six-month follow-up it is commitment that enters. The strongest model for predicting transformational leadership just after the exercise is with the control facet of hardiness (model $R^{2}=0.52$ ), but at the six-month follow-up the strongest model is with hardiness total (model $R^{2}=0.56$ ).

Turning to transactional leadership (Table III) hardiness total score enters as significant only in model 1a, predicting transactional levels just after the exercise. When the facets are allowed to enter, commitment is the consistent predictor of transactional scores just after the exercise (model $R^{2}=0.34$ ), and also at the six-month

\begin{tabular}{|c|c|c|c|c|c|c|c|}
\hline \multirow{2}{*}{$\frac{\text { Regression model }}{\text { 1a. Significant predictors }}$} & \multicolumn{3}{|c|}{$\begin{array}{l}\text { Transformational } \\
\text { style after exercise }\end{array}$} & \multirow{2}{*}{$\begin{array}{l}\text { Regression model } \\
\text { 1b. Significant predictors }\end{array}$} & \multicolumn{3}{|c|}{$\begin{array}{l}\text { Transformational } \\
\text { style at six-month } \\
\text { follow-up }\end{array}$} \\
\hline & $\beta$ & $R^{2}$ & $R^{2} \Delta$ & & $\beta$ & $R^{2}$ & $R^{2} \Delta$ \\
\hline T1 Transformational & $0.55 * *$ & 0.45 & & T1 Transformational & $0.51 * *$ & 0.44 & \\
\hline $\begin{array}{l}\text { Hardiness total } \\
F[2,63]=34.78^{* * *}\end{array}$ & $0.29 *$ & 0.51 & $0.07^{*}$ & $\begin{array}{l}\text { Hardiness total } \\
F[2,63]=42.30\end{array}$ & $0.39 * *$ & 0.56 & $0.12^{* *}$ \\
\hline 2a. Significant predictors & $\beta$ & $R^{2}$ & $R^{2} \Delta$ & 2b. Significant predictors & $\beta$ & $R^{2}$ & $R^{2} \Delta$ \\
\hline T1 Transformational & $0.61^{* *}$ & 0.45 & & T1 Transformational & $0.58^{* *}$ & 0.44 & \\
\hline Control & $0.28^{*}$ & 0.52 & $0.08^{*}$ & Commitment & $0.30^{*}$ & 0.52 & $0.08^{*}$ \\
\hline \multicolumn{4}{|c|}{$\begin{array}{l}F[2,63]=35.50^{* * *} \text {; not in model: } \\
\text { Commitment Challenge }\end{array}$} & \multicolumn{4}{|c|}{$\begin{array}{l}F[2,63]=35.47^{* * *} ; \text { not in model: } \\
\text { Control, Challenge }\end{array}$} \\
\hline
\end{tabular}

Notes: Adjusted $R^{2}$ values are presented. Significance levels indicated as: ${ }^{*} p<0.01 ;{ }^{*} p<0.001$

$$
\text { transactional scores just after the exercise (model } R^{2}=0.34 \text { ), and also at the six-month }
$$

\section{The role of personality hardiness}

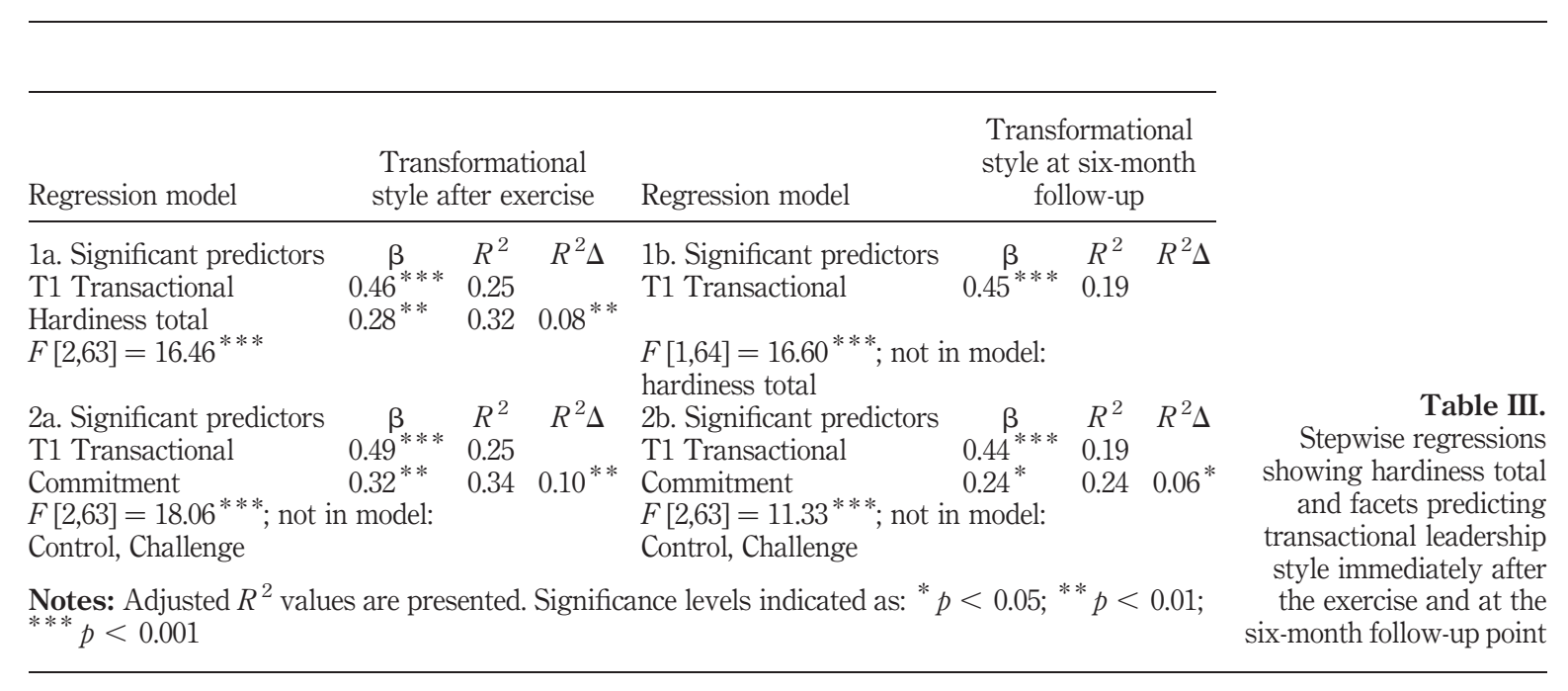




\section{LODJ 29,1}

\section{4}

Table IV.

Stepwise regressions showing hardiness total and facets predicting passive-avoidant leadership style immediately after the exercise and at the six-month follow-up point

\begin{tabular}{|c|c|c|c|c|c|c|c|}
\hline \multirow{2}{*}{$\begin{array}{l}\text { Regression model } \\
\text { 1a. Significant } \\
\text { predictors }\end{array}$} & \multicolumn{3}{|c|}{$\begin{array}{l}\text { Passive-avoidant style } \\
\text { after exercise }\end{array}$} & \multirow{2}{*}{$\begin{array}{l}\text { Regression model } \\
\text { 1b. Significant } \\
\text { predictors }\end{array}$} & \multicolumn{3}{|c|}{$\begin{array}{l}\text { Passive-avoidant style at } \\
\text { six-month follow-up }\end{array}$} \\
\hline & $\beta$ & $R^{2}$ & & & $\beta$ & $R^{2}$ & \\
\hline T1 Passive-avoidant & $0.64 * * *$ & 0.55 & & T1 Passive-avoidant & $0.52^{* * *}$ & 0.38 & \\
\hline $\begin{array}{l}\text { Hardiness total } \\
F[2,63]=49.20 * * *\end{array}$ & $-0.25 * *$ & 0.60 & $0.05^{* *}$ & $\begin{array}{l}\text { Hardiness total } \\
F[2,63]=25.37 * * *\end{array}$ & $-0.25^{*}$ & 0.43 & $0.05^{*}$ \\
\hline $\begin{array}{l}\text { 2a. Significant } \\
\text { predictors }\end{array}$ & $\beta$ & $R^{2}$ & $R^{2} \Delta$ & $\begin{array}{l}\text { 2b. Significant } \\
\text { predictors }\end{array}$ & $\beta$ & $R^{2}$ & $R^{2} \Delta$ \\
\hline T1 Passive-avoidant & $0.58 * * *$ & 0.55 & & T1 Passive-avoidant & $0.51^{* * *}$ & 0.38 & \\
\hline Commitment & $0.43^{* * *}$ & 0.62 & $0.07^{* * *}$ & Challenge & $-0.30^{* *}$ & 0.45 & $0.07^{*}$ \\
\hline Control & $0.22^{* *}$ & 0.65 & $0.04 * *$ & & & & \\
\hline \multicolumn{4}{|c|}{$\begin{array}{l}F[3,62]=41.80^{* * *} ; \text { not in model: } \\
\text { Challenge }\end{array}$} & \multicolumn{4}{|c|}{$\begin{array}{l}F[2,63]=27.60^{* * *} \text {; not in model: } \\
\text { Commitment, Control }\end{array}$} \\
\hline
\end{tabular}

Notes: Adjusted $R^{2}$ values are presented. Significance levels indicated as: ${ }^{*} p<0.05 ;{ }^{* *} p<0.01$; $* * * p<0.001$

follow-up point (model $R^{2}=0.24$ ), with somewhat stronger effects observed just after the exercise.

Finally, for the passive-avoidant style, once again hardiness total predicts scores just after the exercise and at the six-month follow-up. Note that the direction is negative, such that lower hardiness scores are associated with higher passive-avoidance leadership scores. When the hardiness facets are allowed to enter, commitment is a (negative) predictor of passive-avoidant style just after the exercise, but challenge is a (negative) predictor later on at the six-month follow-up. Interestingly, the control facet also is a significant predictor just after the exercise, and is a positive predictor of passive-avoidant style. The strongest model overall includes both commitment $(+)$ and control $(-)$, accounting for 65 percent of the variance in passive-avoidant leadership style just after the exercise (model $R^{2}=0.65$ ).

\section{Predicting leader effectiveness}

The final research question addressed in this study concerns the impact of leadership style on leader performance, as indexed by Military Development (MD) grades in the Navy Officer cadets. Average MD grade points assigned by the independent rating groups were 2.4 ( $S D=0.24$; range 1.8 to 3.1 ). Pearson correlations with one-tailed significance tests revealed no effects for hardiness or pre-exercise (time 1) transformational or transactional leadership styles on MD grades. However, pre-exercise passive-avoidant leadership style was correlated with poor performance grades $(r=0.22, p<0.03)$. The same results obtained with respect to the six-month follow-up leadership style, with only passive-avoidant scores correlated with MD grades $(r=0.22, p<0.04)$. Stronger correlations with MD grades were seen directly after the exercise (time 2), with passive-avoidant style again related to poor performance grades $(r=0.28, p<0.01)$, and also transformational style related to better performance as measured by MD grades $(r=-0.30, p<0.01)$. Correlations of the time 2 (after exercise) leadership scores and personality hardiness with Military Development grades are displayed in Table V. 
Next, a series of multiple regressions were performed with Military Development grades as the dependent variable, and hardiness and leadership scores entered as predictors. No significant effects were found for hardiness, or for time 1 (before the exercise) or time 3 (six-month follow-up) leadership style scores. However, a significant model emerged with the time 2 (just after the exercise) measures, with transformational leadership as a positive predictor of $\mathrm{MD}$ grades, and also transactional style as a negative predictor of MD grade performance. Passive-avoidant style and hardiness did not enter the model. These results are also presented in Table V.

\section{Discussion}

The present study examined the effects of an intensive leadership training experience on self-rated of leadership style in Norwegian Navy officer cadets. Before the exercise these Navy officer cadets showed relatively lower self-ratings of transformational leadership style, as compared to other samples of active duty Norwegian officers (Eid et al., 2004; Johnsen et al., 2006). The present findings show that leadership styles do indeed change over time, following exposure to a stressful training exercise. Levels of transformational and transactional leadership increased on the whole, and passive-avoidant style diminished after the exercise, thus supporting $H 1$ of this research. In addition, these changes were not transitory, but persisted to at least six months following the exercise.

While previous studies have suggested that life histories (Avolio and Gibbons, 1998; Bass, 1998), parental influence (Popper and Mayseless, 2003), and personality factors (Johnsen et al., 2006) could explain individual differences in transformational leadership skills, the present findings provide empirical evidence to suggest that even relatively time limited, but carefully designed and well timed training interventions could promote the development of certain problem-solving and systems skills (Bass and Avolio, 1994; Streufert et al., 1988). It is interesting to note that similar forms of intensive training experiences based on action learning principles (Pedler, 1997), also have been found to influence a number of outcome variables on the team level, such as leader preferences, status hierarchies, and group polarization (Polley and Eid, 1990, 1994), as well as team cohesion (Bartone et al., 2002) in Navy officer cadets. The present study extends these findings by providing empirical evidence to suggest that what leaders do when confronted with challenging situations also might have a powerful

\begin{tabular}{|c|c|c|c|c|c|c|c|c|}
\hline & \multicolumn{4}{|c|}{ Pearson correlations } & & \multicolumn{3}{|c|}{ Stepwise regression } \\
\hline & 1 & 2 & 3 & 4 & 5 & $\beta$ & $R^{2}$ & $R^{2} \Delta$ \\
\hline 1. Transformational & - & & & & & $-0.52^{* * *}$ & 0.08 & \\
\hline 2. Transactional & $0.56^{* * *}$ & - & & & & $0.34 * *$ & 0.16 & $0.08^{* *}$ \\
\hline 3. Passive-avoidance & $-0.37^{* *}$ & -0.23 & - & & & ns & & \\
\hline 4. Personality hardiness & $0.53^{* *}$ & $0.37^{* *}$ & $-0.52^{* * *}$ & - & & ns & & \\
\hline 5. $\mathrm{MD}$ grades $^{\mathrm{a}}$ & $-0.30^{*}$ & 0.04 & $0.28^{*}$ & -0.07 & - & & & \\
\hline
\end{tabular}

Notes: Overall model: $F(2,63)=7.01, p<0.01$.

The table also displays the simple correlations $(n=68)$ among the predictor variables and military development grades.

${ }^{a} \mathrm{MD}$ Grades are reverse-keyed, such that low scores indicate excellent performance. Scores range from $1.0=$ Excellent to $4.0=$ Poor
The role of personality hardiness 
LODJ

29,1

16 reciprocal impact on self-esteem and leadership style. The very nature of the intensive training experience with exposure to novel, challenging problems, and hardships, could promote the innovative and creative thinking that are one characteristic aspect of transformational leadership (Day, 2001; McCauley et al., 1994). In addition to this, the rotation of leadership roles and the structured opportunities for individual and group reflection aided by multi-source feedback sessions throughout the training exercise (Alimo-Metcalfe, 1998), could have contributed to influence self perceptions of leadership skills through social cognitive learning processes (Bandura, 1997). These findings are in accord with Day's (2001) suggestion that leadership development is enhanced to the extent that structured opportunities for individual and group reflection are included as part of an action learning process.

The present study also hypothesized that personality hardiness would be associated with increases in transformational and transactional leadership styles, and decreases in passive-avoidant style following the training exercise. Results provide good support for this hypothesis. In regression models controlling for transformational leadership levels before the exercise (time 1), hardiness predicted transformational leadership at both time points following the exercise. By examining the hardiness facets, it was found that immediately after the exercise this effect has mainly to do with the control dimension, while later in time commitment is more significant. This suggests that having a positive sense or belief in your own ability to maintain control is highly salient especially while directly engaged in a highly stressful experience, a sense that may in turn create a mental frame or set that is open for learning. Conversely, the person who is low in the sense of control in a stressful situation may be more inclined to become defensive and closed-minded, less likely to accept feedback and learn from the experience. At the six-month follow-up point, the hardiness effect on increased transformational style is seen to relate mainly to the commitment facet. This suggests that over time, when the stressful encounter is firmly in the past, it is the ability to integrate and make positive sense of the experience that most facilitates a Transformational leadership style. So it appears that while overall hardiness contributes to a general receptive orientation to positive learning from stressful training experiences, the hardiness control facet may be more salient during the crisis itself, generating a sense of confidence and positive coping expectations. Over the longer-term, the hardiness commitment becomes more salient, perhaps by contributing to the positive interpretation and organizing-integration of past stressful encounters.

Persons high in the hardiness facet of commitment are genuinely more interested in interpersonal relations and in values and priorities in life (Maddi and Kobasa, 1984). This increased involvement in the social world could also increase the readiness to develop those transformational leadership tendencies embedded in the transformational leadership facets of individualized consideration and inspirational motivation. In a similar way, people high in the hardiness facet of challenge are more prone to interpret stressful events in positive and constructive ways. In such settings transformational leaders are expected to enhance the performance capacity of their followers by setting higher expectations and generating a greater willingness to address more difficult challenges (Avolio, 1999; Bass, 1998), which is an important feature of the inspirational motivation factor of transformational leadership. The high hardy person is also authentically interested in and excited about what is going on in the world around him/her, which (especially when focused around desirable group 
goals) would tend to generate among others the kind of admiration and motivation to be-like and be-near that is summarized as "charisma" or idealized influence. Taken together, our findings showed that hardiness acted as a moderator in the development of transformational leadership indicating that high hardy cadets were more successful in utilizing this type of leadership training to develop as transformational leaders. Furthermore, these findings suggests that the moderating effects of individual differences factors such as personality hardiness should be considered in future studies of leader development programs that aim to increase transformational leadership. Other studies have already suggested that emotional intelligence (Barling et al., 2000), and the personality factor of emotional stability (Johnsen et al., 2006) are associated with transformational leadership.

The regression results for transactional leadership style also showed a positive effect for hardiness on increases in transactional style after the exercise, again controlling for time 1 (pre exercise) levels. Here, the commitment facet is most significant. Perhaps this reflects the increased social engagement and awareness that is thought to be associated with hardiness-commitment (Maddi and Kobasa, 1984). As Transactional leadership style emphasizes the value of social exchanges, contingent reward, MBE-A etc., the person who is characteristically more committed and engaged in the social world may also be more ready to learn about the kinds of exchanges that matter most in leadership situations.

Hardiness also appears to influence decreases in passive-avoidant leadership style following a stressful exercise. Here, an examination of the hardiness facets reveals that just after the exercise, it is mainly commitment that is associated with decreased passive avoidant style, while later on the hardiness challenge facet is more salient. A possible explanation is that during a highly stressful encounter, being low on commitment, which entails a characteristic distancing or alienation from one's social and experiential world, contributes to a defensive and closed-minded approach and leads to the rather negative outcome of increased passive-avoidant leadership behaviors. At the six-month follow-up, it is interesting to see that the hardiness challenge facet is the significant (negative) predictor of increased passive-avoidant leadership. This is understandable when one considers that the low-challenge person is one who avoids changing or novel situations, and generally seeks to maximize predictability and security. Exposed to stressful training experiences, cadets low in challenge may react with an even stronger tendency to avoid making changes or taking any actions, just the kinds of behaviors that characterize the passive-avoidant leader. If this interpretation is correct, then stressful training exercises like the one described here that are designed to increase positive growth and leader development, could have just the opposite effect for that subgroup of people who are low in hardiness. This is an important finding that carries implications for selection, as well as the shaping of training experiences so as to be most effective for certain types of individuals.

Somewhat surprisingly, the control facet of hardiness was positively associated with increased passive-avoidance scores just after the exercise. To understand this, it should be remembered that the three hardiness facets are highly intercorrelated. In this sample, commitment and control are correlated at $r=0.50(p<0.001)$. This introduces a multicollinearity effect in regression models. Thus, when the (negative) effects of commitment on increased passive-avoidant leadership are removed from the

\section{The role of personality hardiness}


LODJ 29,1

18

model, the expected (negative) influence of control is also removed, to some extent. After this step, the variance that remains in control facet scores may represent an aspect of control that is not positive but negative in overall effects, especially as regards leadership. Rather than the hardy tendency to be in control of and manage oneself in relation to the world, this "dark side" of control may reflect the tendency to be controlling of others, to over-control or "micromanage" other people and situations. This finding also implies that the hardiness control scale is not a pure measure of that positive sense of self-control and responsibility that belongs to the hardiness style, but is partly contaminated by a negative form of control or over-controlling tendency. This is an important measurement (as well as conceptual) issue that should be addressed with further research.

According to our expectations, self-rated transformational leadership after the exercise emerged as a significant predictor of performance of Navy officer cadets, as indexed by Military Development grades. This is in accord with other studies that have linked transformational leadership to improved performance (Avolio et al., 1999; Bass, 1998; Bass et al., 2003; Kane and Tremble, 2000). Somewhat surprisingly, transactional leadership was a negative predictor of performance in the regression model. Here, we are likely seeing the effects of some multicollinearity between transformational and transactional leadership styles, as they are quite substantially intercorrelated in this sample $(r=0.56, p<0.001)$. Thus, once the positive influence of transformational leadership is removed from the model, what is left with transactional leadership is some underlying negative aspect of this style, perhaps related to an overly rigid and calculating management of tasks and rewards in the work environment. Still another notable finding was that only transformational and transactional leadership after the exercise emerged as predictors of $\mathrm{MD}$ grades. This suggests that cadets rated themselves accurately after the exercise (perhaps an effect of the exercise itself and the feedback it included), and also that their self-ratings as well as the performance ratings of outside observers are based upon actual, observable leadership behaviors of cadets.

Some possible limitations to this study deserve mention. One is the reliance on self-ratings of leadership style, which can introduce bias from individual factors such as the fundamental attribution error (Kosslyn and Rosenberg, 2001), defensiveness in self-perception (Steele and Ovalle, 1984), maintenance of self-esteem (Gioia and Sims, 1985), as well as contextual factors like different frames of references (Hauenstein and Foli, 1989). Although self-report data are fallible, an increasing body of research supports the use of such ratings. In the present study, the finding that self-ratings of leadership are significantly correlated with external observer ratings of performance (MD Grades) given later in time lends support to the accuracy of the self-ratings. Theoretical considerations also led us to prefer self-ratings in this study. Under the Full Range of Leadership Model - FRLM, cadets' perceptions of their own transformational leadership levels could be an important indicator of their leader development potential. Since the subjects under study are Navy officer cadets, knowledge about effective leadership behavior represents a basic aspect of their future readiness to act as military leaders. Developmental readiness could be viewed as the Navy cadet's awareness of the preferred leadership behavior. Self-ratings of leadership style could therefore be seen to represent a growth potential and an important aspect of the young leader candidate's readiness to develop as a leader. 
Another potential limitation is that hardiness scores were collected after the leadership exercise, while hardiness is analyzed as a potential moderator of the effects of the exercise on leadership styles. While it would perhaps be preferable to have hardiness scores from before the exercise, personality hardiness is a stable characteristic that doesn't change much over time (Ouellette, 1993). In support of stability, hardiness test-retest correlation over a three-month period is reported at $r=0.78$ (Bartone, 1998.). While it is theoretically possible for hardiness levels to increase or decrease slightly in adulthood based upon experiences and possibly training (Maddi, 2002), hardiness is a largely stable individual construct and there is ample evidence in support of stability. Also, the relatively small sample of military cadets in the present study could limit the generalizability of our findings. On the other hand, the relative homogeneity of the participants also represents an advantage in terms of limiting the number of possible confounding factors.

Finally, since leadership style as well as hardiness levels were assessed by means of self-report questionnaire, there is the possibility that observed relations between these variables were artificially inflated by common method variance ("mono-method bias"). While some such method bias is possible, the relations observed are substantial enough to generate confidence in their real significance. Furthermore, as several authors have recently pointed out, problems associated with "mono-method bias" are likely overstated and may represent an oversimplification of the true state of affairs (Spector, 2006).

Despite the above-mentioned limitations, this is one of few empirical studies to apply a prospective, longitudinal design to examine the potential effects of leadership training (Day, 2001). Findings from this study regarding personality hardiness and both transformational and transactional leadership could have potential implications for selection and leader development. From a selection perspective, we expect that it could be relevant to consider personality hardiness as a potential selection criterion when choosing leaders for highly challenging and stressful assignments. With respect to leadership development, trainers can make more useful distinctions between different levels of personality hardiness in order to recognize individual training needs, aspirations, and abilities. In pointing out the significance of personality hardiness, the present study also supports previous research that have indicated that carefully designed, challenging, and intensive leadership training experiences can have a sustained impact on self-ratings of leadership style in young officer cadets. Future research should also consider including other related constructs side-by-side with hardiness, such as locus of control, self efficacy, or emotional intelligence in a prospective design.

\section{Note}

1. A comparison between the present year 2000 Norwegian Navy officer cohort and the following year 2001 cohort revealed no significant differences in total hardiness scores. Furthermore, the 2001 cohort showed no overall change in total hardiness over the first year (ten months) at the Norwegian Naval Academy. The ten-month test-retest correlations for this sample for the commitment, control, and challenge facets were $(0.33,0.43$, and 0.67 , respectively with all $p<0.01$.

\section{The role of personality hardiness}


LODJ

29,1

20

\section{References}

Alimo-Metcalfe, B. (1998), “360 degree feedback and leadership development”, International Journal of Selection and Assessment, Vol. 6, pp. 35-44.

Anastasi, A. (1988), Psychological Testing, Macmillan Publishing Company, New York, NY, pp. 122-6.

Atwater, L.E., Dionne, S.D., Camobreco, J.F., Avolio, B.J. and Nau, A. (1998), "Individual attributes and leadership style: predicting the use of punishment and its effects", Journal of Organizational Behavior, Vol. 19, pp. 559-76.

Avolio, B.J. (1999), Full Leadership Development: Building The Vital Forces in Organizations, Sage, Thousand Oaks, CA.

Avolio, B.J. and Bass, B.M. (1991), The Full Range Leadership Development Programs: Basic and Advanced Manuals, Bass, Avolio \& Associates, Binghamton, NY.

Avolio, B.J. and Gibbons, T.C. (1998), "Developing transformational leaders: a life span approach", in Conger, J.A. and Kanungo, R.N. (Eds), Charismatic Leadership: The Elusive Factor in Organizational Effectiveness, Jossey-Bass, San Francisco, CA, pp. 276-308.

Avolio, B.J. and Bass, B.M. (2002), Manual for the Multifactor LeadershipQuestionnaire (Form $5 X)$, Mindgarden, Redwood City, CA.

Avolio, B.J., Bass, B.M. and Jung, D.I. (1999), "Re-examining the components of transformational and transactional leadership using the multifactor leadership questionnaire", Journal of Occupational and Organizational Psychology, Vol. 72, pp. 441-62.

Bandura, A. (1997), The Exercise of Control, Freeman, New York, NY.

Barling, J., Slater, F. and Kelloway, K.E. (2000), "Transformational leadership and emotional intelligence: an exploratory study", Leadership \& Organization Development Journal, Vol. 21, pp. 157-61.

Barling, J., Weber, J. and Kelloway, E.K. (1996), "Effects of transformational leadership training on attitudinal and financial outcomes: a field experiment", Journal of Applied Psychology, Vol. 81, pp. 827-32.

Bartone, P.T. (1995), “A short hardiness scale”, paper presented at the Annual Convention of the American Psychological Society, New York, NY.

Bartone, P.T. (1998), "Test-retest reliability of the short hardiness scale", unpublished manuscript, Department of Behavioral Sciences and Leadership, US Military Academy, West Point, NY.

Bartone, P.T. (1999), "Hardiness protects against war-related stress in Army reserve forces", Consulting Psychology Journal, Vol. 51, pp. 72-82.

Bartone, P.T. (2000), "Hardiness as a resiliency factor for United States forces in the Gulf War", in Violanti, J.M., Paton, D. and Dunning, C. (Eds), Posttraumatic Stress Intervention: Challenges, Issues, and Perspectives, Thomas, Springfield, IL, pp. 115-33.

Bartone, P.T. (2001), "Leader development at the service academies - current and future directions", paper presented at the American Psychological Association Annual Meeting: San Francisco, CA.

Bartone, P.T. (2006), "Resilience under military operational stress: can leaders influence hardiness?", Military Psychology, Vol. 18, pp. 131-48.

Bartone, P.T., Ursano, R.J., Wright, K.M. and Ingraham, L.H. (1989), "The impact of a military air disaster on the health of assistance workers: a prospective study", Journal of Nervous and Mental Disease, Vol. 177, pp. 317-28. 
Bartone, P.T., Johnsen, B.H., Eid, J., Brun, W. and Laberg, J.C. (2002), "Factors influencing small unit cohesion in Norwegian Navy officer cadets", Military Psychology, Vol. 14, pp. 1-22.

Bass, B.M. (1985), Leadership and Performance Beyond Expectations, Free Press, New York, NY.

Bass, B.M. (1998), Transformational Leadership, Industrial, Military, and Educational Impact, Lawrence Erlbaum Associates, Hillsdale, NJ.

Bass, B.M. and Avolio, B.J. (1994), "Transformational leadership and organizational culture", International Journal of Public Administration, Vol. 17, pp. 541-54.

Bass, B.M., Avolio, B.J., Jung, D.I. and Beson, Y. (2003), "Predicting unit performance by assessing transformational and transactional leadership", Journal of Applied Psychology, Vol. 88, pp. 207-18.

Burns, J.M. (1978), Leadership, Harper \& Row, New York, NY.

Contrada, R.J. (1989), "Type A behavior, personality hardiness, and cardiovascular responses to stress", Journal of Personality and Social Psychology, Vol. 57, pp. 895-903.

Day, D.V. (2001), "Leadership development: a review in context”, Leadership Quarterly, Vol. 11, pp. 581-613.

Den Hartog, D.N., Van Muijen, J.J. and Koopman, P.L. (1997), "Transactional versus transformational leadership: an analysis of the MLQ", Journal of Occupational and Organizational Psychology, Vol. 70, pp. 19-34.

Dvir, T., Eden, D., Avolio, B.J. and Shamir, B. (2002), "Impact of transformational leadership on follower development and performance: a field experiment", Academy of Management Journal, Vol. 45, pp. 735-44.

Eid, J., Brun, W., Laberg, J.C. and Johnsen, B.H. (1998), "Participating in a prisoner-of-war exercise: stress reactions and coping", Proceedings from the International Applied Military Psychology Meeting, Paris, France: Department of Defense, pp. 121-126.

Eid, J., Johnsen, B.H., Brun, W., Laberg, J.C., Larsson, G. and Nyhus, J.K. (2004), "Situation awareness and transformational leadership in senior military leaders: an exploratory study", Military Psychology, Vol. 16, pp. 203-9.

Florian, V., Mikulincer, M. and Taubman, O. (1995), "Does hardiness contribute to mental health during a stressful real life situation? The role of appraisal and coping", Journal of Personality and Social Psychology, Vol. 68, pp. 687-95.

Gioia, D.A. and Sims, H.P. (1985), "Self-serving bias and actor-observer differences in organizations: an empirical analysis", Journal of Applied Social Psychology, Vol. 15, pp. $547-63$.

Griffith, J.E. (1988), "The measurement of group cohesion in US Army units”, Basic and Applied Social Psychology, Vol. 9, pp. 149-71.

Hater, J.J. and Bass, B.M. (1988), "Superiors' evaluations and subordinates' perceptions of transformational and transactional leadership", Journal of Applied Psychology, Vol. 73, pp. 695-702.

Hauenstein, N.M. and Foli, R.J. (1989), "From laboratory to practice: neglected issues in implementing frame-of-reference rater training", Personnel Psychology, Vol. 41, pp. 43-62.

Hetland, H. and Sandal, G.M. (2003), "Transformational leadership in Norway: outcomes and personality correlates”, European Journal of Work and Organizational Psychology, Vol. 12, pp. 147-70.

House, R.J. and Shamir, B. (1993), "Toward the integration of transformational, charismatic, and visionary theories", Leadership Theory and Research, Perspectives and Direction, Academic Press, New York, NY, pp. 81-107.
The role of personality hardiness 
LODJ

29,1
Howell, J.M. and Avolio, B.J. (1993), "Transformational leadership, transactional leadership, locus of control, and support for innovation: key predictors of consolidated business unit performance", Journal of Applied Psychology, Vol. 7, pp. 891-902.

Ingraham, L.H. and Manning, F.J. (1981), "Cohesion: who needs it, what is it and how do we get it to them?”, Military Review, Vol. 61, pp. 3-12.

Johnsen, B.H., Eid, J., Larsson, G., Brun, W., Laberg, J.C. and Barlaug, D.G. (2006), Predicting Transformational Leadership: The Effects of Big Five Personality Traits, forthcoming.

Kane, T.D. and Tremble, T.R. Jr (2000), "Transformational leadership effects at different levels of the army", Military Psychology, Vol. 85, pp. 751-65.

Keller, T. (1999), "Images of the familiar: individual differences and implicit leadership theories", The Leadership Quarterly, Vol. 10, pp. 589-607.

Kirkland, F.R., Bartone, P.T. and Marlowe, D.H. (1993), “Commanders' priorities and psychological readiness", Armed Forces and Society, Vol. 19, pp. 579-98.

Kobasa, S.C. (1979), "Stressful life events, personality and health: an inquiry into hardiness", Journal of Personality and Social Psychology, Vol. 37, pp. 1-11.

Kobasa, S.C., Maddi, S.R. and Kahn, S. (1982), "Hardiness and health: a prospective study", Journal of Personality and Social Psychology, Vol. 42, pp. 168-77.

Kosslyn, S.M. and Rosenberg, R.S. (2001), Psychology: The Brain, The Person, The World, Allyn \& Bacon, Boston, MA.

Laberg, J.C., Eid, J., Johnsen, B.H., Eriksen, B.S. and Zachariassen, K.K. (2000), "Coping with interrogations", in McCann, C. and Pigeau, R. (Eds), The Human in Command: Exploring Issues in Military Social Science, Kluwer Academic Publishers, Dordrecht, pp. 333-4.

Lowe, K.B., Kroeck, K.G. and Sivasubramaniam, N. (1996), "Effectiveness correlates of transformational and transactional leadership: a meta-analytic review of the MLQ literature", Leadership Quarterly, Vol. 7, pp. 385-425.

McCauley, C.D., Ruderman, M.N., Ohlott, P.J. and Morrow, J.E. (1994), "Assessing the developmental components of managerial jobs”, Journal of Applied Psychology, Vol. 79, pp. 544-60.

Maddi, S.R. (2002), "The story of hardiness: twenty years of theorizing, research and practice", Consulting Psychology Journal, Vol. 54, pp. 173-85.

Maddi, S.R. and Kobasa, S.C. (1984), The Hardy Executive, Jones-Irwin, Homewood, IL.

Ouellette, S.C. (1993), "Inquiries into hardiness", in Goldberger, L. and Breznitz, S. (Eds), Handbook of Stress: Theoretical and Clinical Aspects, 2nd ed., Free Press, New York, NY, pp. $77-100$.

Patterson, C., Fuller, J.B., Kester, K. and Stringer, D.Y. (1995), “Ameta-analytic examination of leadership style and selected compliance outcomes", paper presented at the 10th Annual Conference of the Society for Industrial and Organizational Psychology, Orlando, FL.

Pedler, M. (1997), "Interpreting action learning”, in Burgoyne, J. and Reynolds, M. (Eds), Management Learning. Integrating Perspectives in Theory and Practice, Sage, London, pp. 248-64.

Polley, R.B. and Eid, J. (1990), "Leadership training on the Bergen Fjord: a case study and evaluation", Group and Organizational Studies, Vol. 15, pp. 192-211.

Polley, R.B. and Eid, J. (1994), "First among equals: leaders, peers and choice", International Journal of Group Psychoterapy, Psychodrama and Sociometry, Vol. 47, pp. 59-76.

Popper, M. and Mayseless, O. (2003), "Back to basics: applying a parenting perspective to transformational leadership”, The Leadership Quarterly, Vol. 14, pp. 41-65. 
Roth, D.L., Wiebe, D.J., Fillingim, R.B. and Shay, K.A. (1989), "Life events, fitness, hardiness, and health: a simultaneous analysis of proposed stress-resistance effects", Journal of Personality and Social Psychology, Vol. 57, pp. 136-42.

Spector, P.E. (2006), "Method variance in organizational research: truth or urban legend?", Organizational Research Methods, Vol. 9, pp. 221-32.

Steele, R.P. and Ovalle, N.K. (1984), "Self-appraisal based on supervisory feedback", Personnel Psychology, Vol. 37, pp. 347-51.

Streufert, S., Nogami, G., Swezey, R.W., Pogash, R.M. and Piasecki, T. (1988), "Computer assisted training of complex managerial performance", Computers in Human Behavior, Vol. 4, pp. 77-88.

Waldman, D.A., Bass, B.M., Einstein, W.O. (1987), "Effort performance and transformational leadership in industrial and military service", Journal of Occupational Psychology, Vol. 60, pp. 1-10.

Waldman, D.A., Bass, B.M. and Yammarino, F.J. (1990), "Adding to contingent reward behavior: the augmenting effect of charismatic leadership", Group and Organizational Studies, Vol. 15, pp. 381-94.

Wats, B.D. (1996), Clausewitzian Friction and Future War, Institute for National Strategic Study, National Defense University, Washington, DC.

Westman, M. (1990), "The relationship between stress and performance: the moderating effect of hardiness", Human Performance, Vol. 3, pp. 141-55.

Wiebe, D.J. (1991), "Hardiness and stress moderation: a test of proposed mechanisms", Journal of Personality and Social Psychology, Vol. 60, pp. 89-99.

Yukl, G. (1999), "An evaluation of conceptual weaknesses in transformational and charismatic leadership theories", Leadership Quarterly, Vol. 10, pp. 285-305.

Zacharatos, A., Barling, J. and Kelloway, E.K. (2000), "Development effects of transformational leadership in adolescents", Leadership Quarterly, Vol. 11, pp. 211-26.

\section{Corresponding author}

Jarle Eid can be contacted at: Jarle.eid@psysp.uib.no
The role of personality hardiness

To purchase reprints of this article please e-mail: reprints@emeraldinsight.com Or visit our web site for further details: www.emeraldinsight.com/reprints 